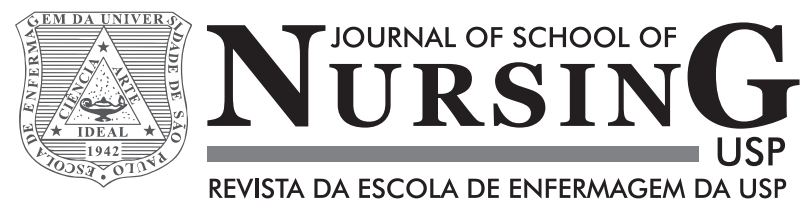

\title{
Nursing workload in specialized Semi-intensive Therapy unit: workforce size criteria
}

\author{
Carga de trabalho de enfermagem em unidade de Terapia Semi-intensiva especializada: \\ critérios para dimensionamento de pessoal \\ Carga de trabajo de enfermería en unidad de Cuidados Semi-intensivos especializada: \\ criterios para dimensionamiento de personal
}

\author{
Armando dos Santos Trettene ${ }^{1,2}$, Aline Godoi Luiz ${ }^{3}$, Ana Paula Ribeiro Razera ${ }^{1}$, Thaís de Oliveira Maximiano ${ }^{3}$, Flavia Maria \\ Ravagnani Neves Cintra ${ }^{1}$, Laressa Manfio Monteiro ${ }^{4}$
}

\footnotetext{
${ }^{1}$ Universidade de São Paulo, Hospital de Reabilitação de Anomalias Craniofaciais, Programa de Pós-Graduação em Ciências da Reabilitação, Bauru, SP, Brazil.

${ }^{2}$ Universidade Paulista, Bauru, SP, Brazil.

${ }^{3}$ Universidade de São Paulo, Hospital de Reabilitação de Anomalias Craniofaciais, Programa de Pós-Graduação, Residência Multiprofissional em Saúde, Bauru, SP, Brazil.

${ }^{4}$ Universidade Estadual Paulista "Júlio de Mesquita Filho”, Programa de Pós-Graduação em Enfermagem, Botucatu, SP, Brazil.
}

\begin{abstract}
Objective: To assess the nursing workload (NW) in Semi-intensive Therapy Unit, specialized in the care of children with Craniofacial anomalies and associated syndromes; to compare the amount of workforce required according to the Nursing Activities Score (NAS) and the COFEN Resolution 293/04. Method: Cross-sectional study, whose sample was composed of 72 patients. Nursing workload was assessed through retrospective application of the NAS. Results: The NAS mean was $49.5 \%$. Nursing workload for the last day of hospitalization was lower in patients being discharged to home $(p<0.001)$ and higher on the first compared to last day of hospitalization $(\mathrm{p}<0.001)$. The number of professionals required according to NAS was superior to the COFEN Resolution 293/04, being 17 and 14, respectively. Conclusion: The nursing workload corresponded to approximately $50 \%$ of the working time of nursing professional and was influenced by day and outcome of hospitalization. The amount of professionals was greater than that determined by the existing legislation.
\end{abstract}

DESCRIPTORS

Workload; Nursing; Nursing Staff; Cleft Lip; Cleft Palate; Intensive Care Units. 


\section{INTRODUCTION}

Nursing workload (NW) is directly related to the adequacy of human resources, quality of care, including patient safety, and consequently, the cost reduction ${ }^{(1)}$. In addition, the negative influence on worker's health, particularly when the nursing staff is undersized, causing discontent, physical and mental overload, absenteeism and stress, including Burnout syndrome ${ }^{(2)}$.

NW assessment became a healthcare instrument that is indispensable for the administration of hospitals, aimed not only to quantitative, but qualitative appropriateness of professionals. Various indexes or instruments have been developed in order to quantify accurately the $\mathrm{NW}$, considering the complexity of care and the work process ${ }^{(3)}$.

Among the instruments available to measure the NW, Nursing Activities Score (NAS) is named as one of the most comprehensive, for representing with greater emphasis the reality, according to the latest version of the Therapeutic Intervention Scoring System (TISS-28). It allows one to measure direct and indirect nursing activities, besides being applicable in different contexts, which is why we chose for the present study ${ }^{(4-5)}$, in addition to being translated and validated to the Brazilian reality ${ }^{(6)}$.

Due to the lack of a theoretical framework to address the specific needs of different patients, including pediatric, the Brazilian Federal Council of Nursing (COFEN), through Resolution 293, published in 2004 ${ }^{(7)}$, defines minimum parameters for the team of nursing professionals. Based on Patient classification system, it considers the amount of hours of assistance per bed in 24 hours. It also presents the division of nursing professionals by category, according to the profile of care. Semi-intensive care corresponds to 9.4 nursing hours, and the team should be made up of 42 to $46 \%$ of nurses, complemented by nursing technicians ${ }^{(7)}$.

The semi-intensive care unit (SICU) is defined as the "healthcare structure that provides physical facilities, equipment and human adequate resources to provide specialized assistance in serious or potentially serious patients" ${ }^{(7)}$. In this context, SICUs are present in hospital institutions, regardless of the profile of the customers, including hospitals designated to the care of patients with cleft lip and palate and related anomalies.

The cleft lip and palate malformations do not represent most common syndromic cleft lip and/or palate craniofacial involvement, involving aesthetic, functional and psychosocial problems ${ }^{(8)}$. The functional problems are internalized when they are associated with genetic syndromes and/or clinics, including respiratory and food problems in most cases. Usually, surgeries are necessary which involve specific nursing care, in addition to the need for training of caregivers to maintain these care after discharge $\mathrm{e}^{(9)}$. These include, for example, tracheostomy, gastrostomies, dysphagia requiring gastric probes feed, etc. In this context, the nurse carries out essential function, acting primarily as an educator in promoting self-care ${ }^{(10)}$.

Given the above, the following question arises: what is the NW on specialized pediatric care Semi-intensive therapy units for children with Craniofacial anomalies and associated syndromes? and what is the relationship between the amount of workforce required according to NAS and the resolution of COFEN-293/04(7)? Thus, the objectives of this study are: to assess the NW in specialized pediatric care SICU in children with Craniofacial anomalies and associated syndromes and compare the amount of workforce required according to NAS and COFEN resolution 293/04(7).

We believe this study will contribute to the proper size of staff, influencing directly the quality of care in all its proportions, covering not only the patients, but the team as a whole.

\section{METHOD}

Descriptive, cross-sectional study with quantitative design, conducted in specialized pediatric care SICU for children with cleft lip and palate and Craniofacial anomalies of a referral Hospital.

The unit is composed of eight beds, intended for the care of children under two years of age, affected by craniofacial malformations, associated or not to cleft lip and palate, which usually evolve into respiratory changes and dysphagia. Besides that, this unit aims at promoting the training of caregivers (promoting self-care) for maintenance of the child care after discharge.

The population was composed of children who were admitted in the unit, in the period of data collection, during the period from May to July 2014. Since the first day of data collection, NAS was applied to all children, being allocated as they were admitted, corresponding entirely the period of hospitalization. The sample consisted of $72 \mathrm{pa}-$ tients, equivalent to all hospitalized children in the period of data collection.

The research began after approval of the Research Ethics Committee involving Humans, by the protocol 636,573. Due to the fact that the measurement of the NW is a routine procedure, we developed a term of commitment to ensure the observation of ethical precepts according to 466/12 Resolution of the Brazilian National Health Council.

In order to assess the NW we used NAS. This is a translated and validated instrument to the Brazilian reality, quantitative adequate, by means of percentage of actual time spent by a nursing professional in direct and indirect healthcare to the patient during 24 hours, which the maximum value is $176.8 \%$. Thus, values above $100 \%$ indicate that a professional is necessary to meet the needs of a single patients in 24 hours ${ }^{(5-6)}$.

The patients were followed-up during the entire length of hospitalization. The NW was assessed through retrospective application of NAS, being applied on a daily basis, in the morning period, exclusively by researchers. All researchers have been previously trained, and a tutorial was created regarding the application, in order to standardize data collection.

For the assessment of NW, as well as systematic observation, we listed information during shift change, in addition to the notes in the medical chart. A total of 586 assessments were generated regarding NAS application. 
The NW was associated with age, medical diagnosis and outcome of hospitalization (Discharge, transfer to ICU, transfer to home city and transfer to the inpatient Unit). Subsequently, the amount of daily workforce according to the NAS was compared to the number of daily workforce according to COFEN resolution 293/04(7), about workforce size.

For the performance of sizing of the nursing staff according to the NAS, we used the mathematical equation below, consisting of the following variables: the NAS of each day (in hours), working hours and productivity of the professionals ${ }^{(11)}$.

$$
Q=\frac{\sum N A S i}{t \cdot p}
$$

Legend:

$Q=$ daily quantity of nursing staff

$\sum N A S i=$ total NAS (in hours) sector i from collecting day

$t=$ working hours of nursing professionals (6 hours)

$p=$ productivity $(0.80)$

For the performance of the sizing of the nursing staff according to COFEN resolution 293/04, the mathematical equation below was used, it consists of the following variables: nursing hours, Marine constant and occupancy rate ${ }^{(7)}$.

$$
\begin{aligned}
& T H E=T O \times H E \\
& Q P=K M \times T H E
\end{aligned}
$$

Legend:

$H E=$ Nursing hours

$K M=$ Marine constant

$Q P=$ Number of staff

$T H E=$ Total hours of nursing

$T O=$ Occupancy rate

For the comparison of NW according to gender, we used the Mann-Whitney test. For their correlation with age, the Spearman's rank correlation coefficient was used. To analyze the NW according to medical diagnosis and the outcome of the hospitalization, the Kruskal-Wallis test was used, and when there was significant difference, the Dunn method. The Wilcoxon test has made the comparison between the mean on the first day and the last day of hospitalization. For all tests we adopted a significance level of 5\%.

\section{RESULTS}

A total of 72 patients participated in this study. From which, 586 assessments were generated. The NAS mean (95\% CI - Confidence Interval) corresponded to the hospitalization period $49.5 \%(48.4-50.6)$. The mean hospitalization time was 8.1 days (6.9-9.3). The NAS mean on the first day of hospitalization was $69.4 \%$ (66.5-72.3), while the last day was $59.8 \%$ (57.7-61.9).

In relation to the characterization of the patients, the female gender was prevalent $(62.5 \%, n=45)$, with mean age of 83.6 days (70.4-96.8). To analyze the hospitalization outcome, the most frequent was discharge to home ( $84 \%$, $\mathrm{n}=60$ ). Regarding medical diagnosis, the most frequent was the isolated Robin sequence $(49 \%, n=35)$.

Considering the frequency of NAS therapeutic interventions, the most frequent items were: monitoring and controls $(\mathrm{n}=586,100 \%)$, medication, except vasoactive drugs $(\mathrm{n}=586,100 \%)$, hygiene procedure $(\mathrm{n}=586,100 \%)$, mobilization and positioning $(\mathrm{n}=586,100 \%)$, support and care to the families and patients $(\mathrm{n}=586,100 \%)$, administrative and managerial tasks $(\mathrm{n}=586,100 \%)$, care with artificial airways $(n=583,99 \%)$ and enteral nutrition $(n=586,100 \%)$ (Table 1). It is worth mentioning that the unlisted items correspond to those with zero frequency.

Table 1 - Frequency of therapeutic interventions of the Nursing Activities Score (NAS) according to items - Bauru, SP, Brazil, 2015.

\begin{tabular}{lcc}
\hline Items & $\mathbf{n}$ & $\%$ \\
\hline 1. Control and monitoring & 586 & $100 \%$ \\
2. Laboratory investigations & 155 & $26 \%$ \\
3. Medication except vasoactive drugs & 586 & $100 \%$ \\
4. Hygiene procedures & 586 & $100 \%$ \\
$\begin{array}{l}\text { 6. Mobilization and Positioning } \\
\text { 7. Support and care to the families and patients }\end{array}$ & 586 & $100 \%$ \\
$\begin{array}{l}\text { 8. Administrative and managerial tasks } \\
\text { 9. Respiratory support }\end{array}$ & 586 & $100 \%$ \\
$\begin{array}{l}\text { 10. Care of artificial airway } \\
\text { 11. Treatment for improvement of pulmonary }\end{array}$ & 107 & $18 \%$ \\
function & 583 & $99 \%$ \\
$\begin{array}{l}\text { 21. Enteral nutrition } \\
\text { 23. Specific interventions outside the Intensive }\end{array}$ & 586 & $100 \%$ \\
$\begin{array}{l}\text { Care Unit, including diagnostic or surgical } \\
\text { procedures }\end{array}$ & 47 & $8 \%$ \\
\hline
\end{tabular}

To calculate the right workforce size according to COFEN resolution $293 / 04^{(7)}$, we considered the occupancy rate of $80 \%$, the amount of hours of nursing care for patients in semi-intensive care (9.4 hours of nursing), and Marine's constant (KM) corresponding to the working hours of 36 hours weekly (0.2236). The workforce size was approximately 14 professionals, consisting of six nurses (42\%) and eight nursing technicians (58\%), to be distributed in 24 hours shifts.

For the calculation of the workforce size according to the NAS, we used the NAS mean $49.5 \%$. Whereas each NAS point corresponds to 14.4 minutes $^{(6)}$, it was required 11.88 nursing hours to attend patients in 24 hours. We considered an occupancy rate of $80 \%$ and the index of Technical Safety of 34\% (corresponding to the daily working hours of 6 hours/1 weekly day off), and productivity of $80 \%^{(6)}$. Workforce size, according to NAS, was approximately 17 professionals, seven nurses (42\%) and 10 nursing technicians (58\%), to be distributed in 24 hours shifts.

We observed that the amount of nursing professionals required through the application of NAS was higher (three professionals) compared to COFEN resolution 293/04(7).

When we made a correlation of NAS mean to age $(\mathrm{p}=0.848)$ and compared it according to medical diagnostics $(\mathrm{p}=0.269)$ and the length of hospitalization $(\mathrm{p}=0.426)$, no 
statistical significance was observed. To analyze NAS mean on the last day of hospitalization and outcome of hospitalization, we found significant difference $(\mathrm{p}<0.001)$, patients transferred to ICU presented higher mean when compared to those discharged to home (Table 2).

Table 2 - Comparison of nursing workload for the last day of hospitalization according to outcomes - Bauru, SP, Brazil, 2015.

\begin{tabular}{lccccc}
\hline $\begin{array}{l}\text { Hospitalization } \\
\text { outcome }\end{array}$ & $\mathbf{n}$ & $\mathbf{\%}$ & $\begin{array}{c}\text { NAS } \\
\text { Mean }\end{array}$ & $\mathbf{9 5 \%} \mathbf{C l}$ & $\mathbf{P}$ \\
\hline Discharge to home & 60 & 83.3 & 57.9 & $56.3-59.5$ & \\
Transfer to ICU & 6 & 8.3 & 75.1 & $60.2-90.0$ & \\
Transfer to home city & 3 & 4.1 & 68.6 & $30.4-106.8$ & $<0.001^{*}$ \\
Transfer to IU & 3 & 4.1 & 58.4 & $52.1-64.7$ & \\
\hline
\end{tabular}

Kruskal-Wallis *Significant difference $(\mathrm{p} \leq 0.05)$

Legend: NAS - Nursing Activities Score

When comparing the NAS mean from the first (69.4\%) and the last day (59.8\%) of hospitalization, we found statistically significant difference $(\mathrm{p}<0.001)$ (Table 3$)$.

Table 3 - Comparison between the Nursing Activities Score (NAS) mean of the first day and the last day of hospitalization Bauru, SP, Brazil, 2015.

\begin{tabular}{lccc}
\hline Hospitalization day & NAS Mean & $\mathbf{9 5} \% \mathbf{C l}$ & $\mathbf{P}$ \\
\hline NAS $1^{\text {st }}$ day & 69.4 & $66.5-72.3$ & \\
NAS last day & 59.8 & $57.7-61.9$ & $<0.001^{*}$ \\
\hline
\end{tabular}

Wilcoxon test. ${ }^{*}$ Significant difference $(p \leq 0.05)$

Legend: NAS - Nursing Activities Score

\section{DISCUSSION}

In this study, when analyzing the characteristics of $\mathrm{pa}^{-}$ tients in relation to the gender, it was observed prevalence of female, corroborating the literature that isolate cleft lip and palate are prevalent in the female gender ${ }^{(12)}$. One should consider that the Pierre Robin sequence is the most incident pathology in this unit, being characterized by cleft lip and palate in $90 \%$ of cases $^{(13)}$.

Regarding age, we did not observe influence on nursing workload. The literature points out that the nursing workload is not associated directly with the age of the patients, but the cared patient profile ${ }^{(14)}$.

In relation to medical diagnosis, Pierre Robin sequence remained isolated, being described as a triad of anomalies characterized by micrognathia, glossoptosis with or without cleft lip and palate, events that leads to respiratory obstruction and dysphagia, justifying the hospitalization in SICUs ${ }^{(13)}$. These patients need a variable range of specific nursing care, which necessarily involve the family ${ }^{(15)}$.

As for the hospitalization outcome, discharge was more frequent. The hospitalization is intended, among other dimensions, the caregiver/family training for continuity of care in homecare environment ${ }^{(9-10)}$. A study conducted in adults SICU found that $29 \%$ of patients received hospital discharge, while $28 \%$ were transferred to other units of less complexity, representing the role of SICU in restoring the conditions of patients, preparing them for discharge ${ }^{(16)}$.
NAS mean for the period of hospitalization was $49.5 \%$. Although studies on nursing workload related to this profile of patients are not available, a similar result was observed in a study with adults in $\operatorname{SICU}^{(16)}$.

A research that sought to identify the NW in different nurseries belonging to a neonatal Unit, listed according to the severity of patients at low risk, medium risk, high risk and isolation, showed that the NAS mean was proportional to the complexity of care ${ }^{(11)}$. Another study with the same objective in a Pediatric ICU, found NAS mean greater than $56 \%{ }^{(17)}$. Both allow inference that the greater the complexity, the greater the nursing workload. This correlation was evidenced in this study because patients whose outcome of hospitalization was discharge to their home showed lower NAS mean on the last day, when compared to those transferred to the ICU. The literature emphasizes this correlation ${ }^{(18)}$.

On the other hand, studies on the NW in different units showed various NAS mean, demonstrating that the $\mathrm{NW}$ is related to the profile of the patients, including the extent of dependency, the complexity of diseases, work process, professional profile, availability of equipment and physical plant ${ }^{(19-22)}$.

When comparing the size of the nursing staff according to the NAS and the COFEN resolution 293/04(7), it was observed that the number required by the NAS was higher, corroborating the literature ${ }^{(4,11,23-24)}$.

On the other hand, another research pointed out that the NW measured through the application of the NAS was lower when compared to the COFEN resolution 293/04 ${ }^{(7)}$, associating this result to low complexity of patients due to the absence of semi-intensive care unit at the institution ${ }^{(25)}$. Other study pointed out, among others, the benefits of adequate staffing to quality of care, including smaller index of adverse events ${ }^{(26)}$.

Comparing the NAS mean on the first and last day of hospitalization showed significant regression of the NW. Similar results were observed in other investigations ${ }^{(18,22)}$. We associate this result to the fact that the patients on the first day of hospitalization, require greater care because they are in unfavorable clinical conditions. Additionally, the fact that the family find themselves emotionally fragile, besides being unprepared for self-care are some of the factors that contribute to the increase of the NW.

Regarding NAS assessments of the items, we observed prevalence of basic nursing activities, corroborating the literature $^{(16)}$. It is worth mentioning that the item support and care to the family members was also prevalent, emphasizing the wide scope of NAS in relation to other assessment instruments of the NW, which does not cover, among other aspects, assistance to the family ${ }^{(6)}$.

Before the hospitalization, nurses exercise the advisory and educator function in the teaching-learning process, promoting, in addition to the technical care, the family insertion in the context of care, considering mainly the training of family members for maintenance of care after discharge ${ }^{(9-10)}$.

Systems of education and health guidance are often classified as minimum nursing care, however, require highly skilled and available professionals ${ }^{(27)}$. 
The literature points to the association between high nursing workload and the care and support to family members, including the family stay in the unit during hospitalization $^{(28-29)}$. As much as receive information about patients by the medical professionals, family members wish to be informed about the care provided by nurses, norms and routines of the unit, equipment, among others ${ }^{(30)}$.

Still, the items ventilatory support and tube feeding were frequent in this study. As emphasized earlier, we associate this result to the prevalence of the Pierre Robin sequence, in which the child usually evolves into respiratory changes and dysphagia ${ }^{(13,15)}$. It is clear, therefore, the viability of the NAS application in different contexts and patient profiles, as advocated by its authors ${ }^{(5-6)}$.

Given the above, it is believed that this study contributed to assess NW in a specialized SICU, while promoting a situational diagnosis linked to the profile of nursing care, contributing to the correct staff sizing. The scarcity of similar studies limits the discussion, but explains the relevance of the present study.

It is known that the appropriate sizing of staff is a ma- jor challenge ${ }^{(3)}$, however, we strongly believe that it is only through the application of scientific methods that we will be able to minimize or solve this problem.

Currently, many evidence has been given to factors associated with patient safety and quality of care. The literature points out the benefits of quantitative and qualitative adequacy of nursing professionals, whose operating costs are lower when compared to those resulted from negative events and outcomes from the assistance provided ${ }^{(31-32)}$.

In this context, we encourage research on workforce size, demonstrating not only the amount of people, but their relationship with the available staff and influence on quality indicators. We reinforce the importance of studies that seek to assess the impact of the training of caregivers and assistance to family members about the NW.

\section{CONCLUSION}

NW corresponded to approximately $50 \%$ of the nursing professional working hours and it was influenced by the day and hospitalization outcome. The nursing staff size was greater than the existing number required by legislation.

\section{RESUMO}

Objetivo: Avaliar a carga de trabalho de enfermagem (CTE) em Unidade de Terapia Semi-intensiva, especializada no atendimento de crianças com anomalias craniofaciais e síndromes associadas; comparar o quantitativo de pessoal requerido segundo o Nursing Activities Score (NAS) e a Resolução COFEN-293/04. Método: Estudo transversal, cuja amostra foi de 72 pacientes. A carga de trabalho de enfermagem foi avaliada por meio da aplicação retrospectiva do NAS. Resultados: A média do NAS foi de 49,5\%. A carga de trabalho de enfermagem referente ao último dia de internação foi menor em pacientes que receberam alta para o domicílio $(p<0,001)$ e maior no primeiro dia de internação em comparação ao último $(\mathrm{p}<0,001)$. O quantitativo de profissionais requerido segundo o NAS foi superior ao da Resolução COFEN-293/04, sendo 17 e 14, respectivamente. Conclusão: A carga de trabalho de enfermagem correspondeu a aproximadamente $50 \%$ do tempo de trabalho do profissional de enfermagem e foi influenciada pelo dia e desfecho da internação. O quantitativo de profissionais foi superior ao determinado pela legislação existente.

\section{DESCRITORES}

Carga de Trabalho; Enfermagem; Recursos Humanos de Enfermagem; Fenda Labial; Fissura Palatina; Unidades de Terapia Intensiva.

\section{RESUMEN}

Objetivo: Evaluar la carga de trabajo de enfermería (CTE) en Unidad de Cuidados Semi-Intensivos, especializada en la atención a niños con anomalías craneofaciales y síndromes asociados; comparar el cuantitativo de personal requerido según el Nursing Activities Score (NAS) y la Resolución COFEN-293/04. Método: Estudio transversal, cuya muestra fue de 72 pacientes. La carga de trabajo de enfermería fue evaluada por medio de la aplicación retrospectiva del NAS. Resultados: El promedio del NAS fue del 49,5\%. La carga de trabajo de enfermería referente al último día de estancia hospitalaria fue menor en pacientes que recibieron alta para el domicilio $(p<0,001)$ y mayor el primer día de la estancia en comparación con el último $(p<0,001)$. El cuantitativo de profesionales requerido según el NAS fue superior al de la Resolución COFEN-293/04, siendo 17 y 14, respectivamente. Conclusión: La carga de trabajo de enfermería correspondió a un 50\% del tiempo de trabajo del profesional de enfermería y fue influenciada por el día y resultado de la hospitalización. El cuantitativo de profesionales fue superior al determinado por la legislación existente.

\section{DESCRIPTORES}

Carga de Trabajo; Enfermería; Personal de Enfermería; Labio Leporino; Fisura del Paladar; Unidades de Cuidados Intensivos.

\section{REFERENCES}

1. Kirby E, Hurst K. Using a complex audit tool to measure workload, staffing and quality in district nursing. Br J Community Nurs. 2014;19(5):219-23.

2. Salehi A, Javanbakht M, Ezzatababdi MR. Stress and its determinants in a sample of Iranian nurses. Holist Nurs Pract. 2014;28(5):323-8.

3. Fugulin FMT, Rossetti AC, Ricardo CM, Possari JF, Mello MC, Gaidzinski RR. Nursing care time in the Intensive Care Unit: evaluation of the parameters proposed in COFEN Resolution No 293/04. Rev Latino Am Enfermagem. 2012;20(2):325-32.

4. Brito AP, Guirardello EB. Nursing workload in a inpatient unit. Rev Latino Am Enfermagem. 2011;19(5):1139-5.

5. Miranda DR, Nap R, Rijk A, Schaufeli W, Lapichino G.; TISS Working Group. Therapeutic Intervention Scoring System. Nursing Activities Score. Crit Care Med. 2003:31(2):374-82. 
6. Queijo AF, Padilha KG. Nursing Activities Score (NAS): Cross-cultural adaptation and validation to Portuguese language. Rev Esc Enferm USP. 2009;43(n.spe):1018-25.

7. Conselho Federal de Enfermagem. Resolução n. 293, de 21 de setembro de 2004. Regulamenta os parâmetros para dimensionamento do quadro de profissionais de enfermagem nas instituições de saúde e assemelhados [Internet]. Brasília; 2004 [citado 2010 abr. 10]. Disponível em: http://novo.portalcofen.gov.br/resoluo-cofen-2932004_4329.html

8. Paranaíba LM, Miranda RT, Ribeiro LA, Barros LM, Martelli Júnior H. Frequency of congenital craniofacial malformations in Brazilian Reference Center. Rev Bras Epidemiol. 2011;14(1):151-60.

9. Trettene AS, Mondini CCSD, Marques IL. Feeding children in the immediate perioperative period after palatoplasty: a comparison between techniques using a cup and a spoon. Rev Esc Enferm USP. 2013;47(6):1298-304.

10. Trettene AS, Razera APR, Maximiano TO, Luiz AG, Dalben GS, Gomide MR. Doubts of caregivers of children with cleft lip and palate on postoperative care after cheiloplasty and palatoplasty. Rev Esc Enferm USP. 2014;48(6):993-8.

11. Nunes BK, Toma E. Assessment of a neonatal unit nursing staff: application of the Nursing Activities Score. Rev Latino Am Enfermagem. 2013;21(1):348-55.

12. Cymrot M, Sales FCD, Teixeira FAA, Teixeira Junior FAA, Teixeira GSB, Cunha Filho JF, et al. Prevalência dos tipos de fissura em pacientes com fissura labiopalatinas atendidas em um Hospital Pediátrico do Nordeste Brasileiro. Rev Bras Cir Plást. 2010;25(4):648-57

13. Marques IL, Prado-Oliveira R, Leirião VHV, Jorge JC, Souza L. Clinical and Fiberoptic Endoscopic Evaluation of Swallowing in Robin Sequence Treated With Nasopharyngeal Intubation: The Importance of Feeding Facilitating Techniques. Cleft Palate Craniofac J. 2010;47(5):523-9.

14. Leite IRL, Silva GRF, Padilha KG. Nursing Activities Score and demand of nursing work in intensive care. Acta Paul Enferm. 2012;25(6):837-43.

15. Trettene AS, Fiorotti L. Diagnósticos de enfermagem em lactentes com Sequência de Robin isolada. Nursing (São Paulo). 2011;14(163):641-4.

16. Wolff LDG, Mazur CS, Wiezbicki C, Barros CB, Quadros VAS. Dimensionamento de pessoal de enfermagem na unidade semi-intensiva de um hospital universitário de Curitiba. Cogitare Enferm. 2007;12(2):171-82

17. Campagner AOM, Garcia PCR, Piva JP. Use of scores to calculate the nursing workload in a pediatric intensive care unit. Rev Bras Ter Intensiva. 2014;26(1):36-43.

18. Goulart LL, Aoki RL, Vegian CFL, Guirardello EB. Carga de trabalho de enfermagem em uma unidade de terapia intensiva de trauma. Rev Eletr Enf [Internet]. 2014 [citado 2015 fev. 19];16(2):346-51. Disponível em: https://www.fen.ufg.br/fen_revista/v16/n2/pdf/v16n2a10.pdf

19. Padilha KG, Sousa RMC, Queijo AF, Mendes AM, Miranda DR. Nursing Activities Score in the Intensive Care Unit: analysis of the related factors. Intensive Crit Care Nurs. 2008;24(3):197-204.

20. Padilha KG, Sousa RMC, Garcia PC, Bento ST, Finardi EV, Hatarashi RHK. Nursing workload and staff allocation in an intensive care unit: a pilot study according to Nursing Activities Score (NAS). Intensive Crit Care Nurs. 2010;26:108-13.

21. Coelho FU, Queijo AF, Andolhe R, Gonçalves LA, Padilha KG. Carga de trabalho de enfermagem em unidade de terapia intensiva de cardiologia e fatores clínicos associados. Texto Contexto Enferm. 2011; 20(4):735-41.

22. Peng L, Mayner L, Wang H. Association between trauma patients' severity and critical care nursing workload in China. Nurs Health Sci. 2014;16(4):528-33.

23. Nunes BK, Toma E. Assessment of a neonatal unit nursing staff: application of the Nursing Activities Score. Rev Latino Am Enfermagem. 2013;21(1):348-55.

24. Inoue KC, Matsuda LM. Sizing the nursing staff in an Intensive Care Unit for Adults. Acta Paul Enferm. 2010;23(3):379-84.

25. Panunto MR, Guirardello EB. Nursing workload in an intensive care unit of a teaching hospital. Acta Paul Enferm. 2012;25(1):96-101.

26. Aydin C, Donaldson N, Stotts NA, Fridman M, Brown DS. Modeling hospital-acquired pressure ulcer prevalence on medical-surgical units: nurse workload, expertise, and clinical processes of care. Health Serv Res. 2015;50(2):351-73.

27. Nagata Y, Urakawa M, Kobayashi N, Kato S. Analysis on workload for hospital DOTS service. Kekkaku. 2014;89(4):495-502.

28. Athanasiou A, Papathanassoglou ED, Patiraki E, McCarthy MS, Giannakopoulou M. Family visitation in Greek Intensive Care Units: nurses' perspective. Am J Crit Care. 2014;23(4):326-33.

29. Stafseth SK, Solms D, Bredal IS. The characterization of workloads and nursing staff allocation in intensive care units: a descriptive study using the Nursing Activities Score for the first time in Norway. Intensive Crit Care Nurs. 2011;27(5):290-4.

30. Verhaeghe S, Defloor T, Van Zuuren F, Duijnstee M, Grypdonck M. The needs and experiences of Family members of adult patients in an intensive care unit: a review of the literature. J Clin Nurs. 2005;14(4):501-9.

31. Aiken LH, Sloane DM, Bruyneel L, Van den Heede K, Griffiths P, Busse R, et al. Nurse staffing and education and hospital mortality in nine European countries: a retrospective observational study. Lancet. 2014;383(9931):1824-30.

32. Fugulin FMT, Lima AFC, Castilho V, Bochembuzio L, Costa JA, Castro L, et al. Cost of nursing staffing adequacy in a neonatal unit. Rev Esc Enferm USP. 2011;45(n.spe):1582-8. 